\title{
Investigating Market Orientation-Business Performance Relationships in the Yogyakarta (Indonesia) Batik Family Firms
}

\author{
Arif Hartono $^{1}$ \\ ${ }^{1}$ Management Department, Faculty of Economics, Universitas Islam Indonesia (UII), Indonesia \\ Correspondence: Arif Hartono, Management Department, Faculty of Economics, Universitas Islam Indonesia \\ (UII), Yogyakarta, Indonesia. E-mail: arif.hartono@uii.ac.id
}

\author{
Received: February 16, 2013 Accepted: July 16, 2013 Online Published: August 6, 2013 \\ doi:10.5539/ijms.v5n5p31 URL: http://dx.doi.org/10.5539/ijms.v5n5p31
}

\begin{abstract}
Objectives of the this study examines the empirical relationships between market orientation (MO) and family firms' performance and analyzes the effects of moderating variables (market turbulence and competitive intensity) on the relationships between market orientation and family firms' performance of the batik industry in Yogyakarta Province, Indonesia. The result of MO-business performance relationship in the Indonesian batik family firms was consistent with the vast majority of MO studies; however the role of moderator variables (market turbulence and competitive intensity) provided non-significant contribution to the MO-business performance relationship.
\end{abstract}

Keywords: market orientation, performance, family firms, batik industry, Indonesia

\section{Introduction}

Identifying and satisfying customers' need more effective and efficient than competitors is the key marketing concept in order to achieve sustained success (Kotler \& Keller, 2011). Such marketing concept was adopted by Kohli \& Jaworski (1990) to articulate the market orientation (MO) theory. Other scholars, Narver \& Slater (1990) conducted operational measure of MO and their study showed a positive relationship between MO and business profitability. Kohli \& Jaworski (1990) and Narver \& Slater (1990) were the first scholars who studied the antecedents and consequences of MO.

In the MO study, two perspectives can be distinguished. The first sees MO from behavioral perspective that focus on organizational activities that are related to the generation and dissemination of and responsiveness to market intelligence (Kohli \& Jaworski, 1990). The second is cultural perspective that concentrates on organizational norms and values that encourage behaviors that are consistent with market orientation (Deshpande, Farley \& Webster, 1993; Narver \& Slater, 1990).

Objectives of the present study are as follows (1) examining the empirical relationships between MO and family firms' performance of the batik industry in Yogyakarta province, Indonesia; (2) analyzing the effects of moderating variables (market turbulence and competitive intensity) on the relationships between MO and family firms' performance of the batik industry in Yogyakarta province, Indonesia.

Despite MO has been studied in wide range of industries, in both small and large firms; however few previous studies examined MO of family firms (Zachary et al. 2011). Moreover, to the best the present author knowledge, there is few studies examined the study of MO in batik industry in Indonesia. Batik is recognized as the cultural heritage of Indonesia and UNESCO has nominated that Indonesian batik as the intangible cultural heritage of humanity.

Batik industry is classified as one of fourteen creative industries in Indonesia and it has significant to the economic development. For example, export of the industry from Central Java to US generated income USD 29.3 million in 2007. The amount increased $20.24 \%$ from the export activity in 2006, USD 24.4 million (Budiono \& Vincent, 2010). In addition, the industry contributes to the job creation; a data was released in 2007 showed that there were 48,300 business units provided jobs for 792.300 people (Budiono \& Vincent, 2010). The batik industry in Indonesia is dominated by small size of family firms that located mostly in Central Java and Yogyakarta provinces. 
Despite the huge potential income generated from the industry, there are some factors that treat the sustainability of the industry (Budiono \& Vincent, 2010). First, cheaper illegal batik textile from China flooded batik markets in Indonesia. Second, only small numbers of batik products were patented; therefore the condition drives people to hijack and to duplicate the products easily. Even worst, the product was claimed that originally comes from a foreign country. Therefore it can be concluded that the Indonesian batik industry faces both local and international competition. Lastly, most of the firms run traditionally by family members; in contrary only small of the firms managed by professionals and are equipped with modern technology and management.

The significance of the present study can be viewed from conceptual and practical perspectives. From the conceptual point of view, it is hoped that the study's results able to portray the level of market orientation, market turbulence, and competitive intensity in affecting business performance of the Indonesian family firms, more specifically in the batik industry. The study's results are expected to contribute the richness of MO-performance literature in family firms' context in a developing country. From practical perspective, the study's result is expected to provide insight for family firms managers of the batik industry in order to develop MO strategy in the competitive batik market.

\section{Literature Review}

\subsection{Four Consequences of $M O$}

A meta-analysis of MO studies conducted by Kirca, Jayachandran \& Bearden (2005) organized four consequences of MO, namely organizational performance, customer consequences, innovation consequences, and employee consequences. In terms of organizational performance, Kirca, Jayachandran \& Bearden (2005) distinguish the performance into cost-based performance measures (e.g. profit measures) and revenue-based performance measures (e.g. sales and market share). The vast majority of MO studies revealed that being market oriented is associated with superior business performance (Kirca, Jayachandran \& Bearden, 2005). However, some MO studies revealed non-significant or negative association (e.g. Agarwal, Erramilli \& Dev, 2003; Sandvik \& Sandvik, 2003).

Jaworski \& Kohli $(1993,1996)$ argued that customer consequences consist of the perceived quality of firms' products or services, customer loyalty and loyalty with the firms' products and services. Innovation consequences consist of firms' ability to create and implement new ideas, products and process (Hult \& Ketchen, 2001) and new product performance (Im \& Workman, 2004). Lastly, employees' commitment, team spirit, customer satisfaction and job satisfaction can be enhanced by MO.

\subsection{Responsive and Proactive $M O$}

Prior to define two forms of MO, expressed and latent needs will be discussed as the basis of the development of responsive and proactive MO. Narver, Slater \& MacLachlan (2004) defined expressed needs and expressed solutions as a customer's needs and solutions of which the customer is aware and therefore they able to express the needs and solutions. Based on the expressed needs and expressed solutions, responsive MO is defined. Responsive MO is 'a business's attempt to understand and to satisfy customers' expressed needs' (Narver, Slater \& MacLachlan, 2004:336).

Narver, Slater \& MacLachlan (2004:336) defined latent needs and latent solutions as 'needs and solutions of which the customer is unaware'. Due to the customers' unawareness, marketers need to lead them in order to discover and to satisfy their latent needs. Therefore, MO that leads customers rather than merely responds to them is defined as proactive MO (Narver, Slater \& MacLachlan, 2004).

\section{$2.3 \mathrm{MO}$ and Business Performance}

A meta-analysis study conducted by Kirca, Jayachandran \& Bearden (2005) showed that the MO-performance relationship has been the most frequently examined association among the four MO consequences. The meta-analysis also reveals significant positive associations between MO and the performance. In addition, the strength of MO-performance relationship is not influenced by the use single versus multi item performance measures.

Regarding family firms' performance, Subramanian \& Gopalakrishna (2009) stated that quantitative study of MO-family firms' performance relationship is missing in the literature. The present study attempts to empirically test the consequences of $\mathrm{MO}$ on business performance of the batik industry in Yogyakarta province, Indonesia. Therefore the following hypotheses were proposed:

H1 Proactive MO has a positive impact on business performance of the batik family firms.

$\mathrm{H} 2$ Responsive $\mathrm{MO}$ has a positive impact on business performance of the batik family firms. 


\subsection{Moderators of the MO-Performance Relationship}

Previous scholars (e.g. Bennett \& Cooper, 1979; Houston, 1986; Lusch \& Laczniak, 1987; Kohli \& Jaworski, 1990, 1993) argued that the level of MO and its importance can be influenced by environmental condition. In this study, market turbulence and competitive intensity are the environmental context that will be investigated as moderator variables that are expected enhance the relationship between MO and performance. Justification behind the use of the moderator variables is because the batik industry in Indonesia is facing competitive and challenging competition both nationally and internationally as explained in the first part of the present study. Jaworski \& Kohli (1993) argued that market turbulence and competitive intensity are expected able to enhance the impact of $\mathrm{MO}$ on performance when market responsiveness is more important due to an organization deals with aggressive competitors and an evolving mix of customers.

Market turbulence forces organizations to modify their products and services regularly in order to satisfy the changing of customers' preferences. Therefore, such organizations need to be more market oriented compared to organizations in stable markets (Jaworski \& Kohli, 1993). When an organization stays in the high level of competition market, customers have many alternative options to satisfy their needs and wants. Therefore, the following hypotheses were proposed:

H3 Proactive MO-business performance relationship in the batik family firms is moderated by market turbulence.

H4 Proactive MO-business performance relationship in the batik family firms is moderated by competitive intensity.

H5 Responsive MO-business performance relationship in the batik family firms is moderated by market turbulence.

H6 Responsive MO-business performance relationship in the batik family firms is moderated by competitive intensity.

\section{Methodology}

\subsection{Questionnaire}

A self-administered questionnaire was employed in the present study. The questionnaire was divided into six sections. The first and second sections consisted profile of participants and family firms. Questions related to MO were placed in the third section. The fourth and fifth sections consisted of questions related to market turbulence and competitive intensity variables. The last section consisted of business performance variable.

\subsection{Sample}

Prior to distribute the questionnaires, data of the family firms was collected from department of cooperative, small medium and enterprises in the Yogyakarta province. Yogyakarta province is divided into four regions and one city. Table 1 shows name of each region and city as well as number of family firms surveyed. According to the key person from the department, many batik family firms do not register or do not provide information of their profile; therefore it is difficult for the author to count the exact number of the existing batik family firms. Therefore the author decided to employ non-probability sampling due to the probability of selecting population elements is unknown. Another reason to choose non-probability sampling is cost and time factors. Purposive sampling method was used in this study based on the following criteria:

- The batik family firms are owned and controlled by family members;

- The batik family firms already established at least 1 year;

- The batik family firms are located in the inner city of each region and Yogyakarta city.

A total of 200 questionnaires were distributed to participants of the study. The participants were owners, managers or senior staff of the family firms. Such positions were targeted to be the participants with the hope that they have valuable knowledge related to the firms.

The questionnaires were directly distributed to the participants by research assistants. Prior to complete the questionnaires, the participants were asked their willingness and agreement to involve in the study to be the participants by signing a consent letter. The participants were assured of complete anonymity in their responses. The collecting data process consisted of two or more visits to the firms. In almost all the processes, the first visit consisted of leaving the questionnaires with the participants for them to complete. In the second or follow-up visit, the completed questionnaires were collected. A total of 104 usable questionnaires were successfully collected from the participants and the response rate was 52 percent. 
Table 1. Areas and number of the family firms surveyed

\begin{tabular}{lll}
\hline No & Areas Surveyed & Number of Family Firms Surveyed \\
\hline 1 & Yogyakarta city & 50 \\
2 & Sleman & 40 \\
3 & Bantul & 50 \\
4 & Kulon Progo & 30 \\
5 & Gunung Kidul & 30 \\
Total sample & 200 \\
\hline
\end{tabular}

\subsection{Variables and Measures}

Market Orientation: The MO's construct consists of 15 items include 7 items of responsive MO, 8 items of proactive MO that were adopted from Narver, Slater \& MacLachlan (2004) work. A five-Likert scale was used to measure the MO's construct.

Moderators: Market turbulence was measured by using four items adopted from Narver, Slater \& MacLachlan (2004). Competitive intensity was measured on a five-point scale by using six items borrowed from Jaworski \& Kohli (1993).

Performance Measures: Business performance was assessed by subjective measurement on a five-point scale. Business performance dimension consist of the following items: sales volume, profitability, access to market, job creation and employees' productivity. Subjective evaluations were used due to for some reasons. Firstly, the majority of the batik industry is dominated by small scale of firms, therefore it is difficult to obtain desired information from small businesses and it was reckoned to measure performance with subjective assessment (Fiorito \& LaForge, 1986). Secondly, the previous studies showed that subjective measures are a reliable method for evaluating performance (Pearce, Freeman \& Robinson, 1987) and there is a strong association between objective measures and subjective responses (Venkatraman \& Ramanujam, 1986; Robinson \& Pearce, 1988).

Control variables: Three types of control variables were considered: the first was the age of the firm, measured using the logarithm of the number of years it was in existence; the second was the leader of the firms, it was divided into two categories: family member leaders and professional leaders; the third was the family firms' generation who manage the firms and it divided into four generation: from the first to the fourth generation.

\section{Results and Discussion}

\subsection{Profiles of the Participants and the Firms}

The participants and the firms' profiles were analyzed by using simple descriptive statistics. Profile of the participants includes gender, position in the firms, education, and work experience. Table 2 summarises the profile of the participants.

Table 2. Profile of the participants

\begin{tabular}{|c|c|c|c|c|}
\hline \multirow{2}{*}{ Gender } & Man & 36 & 34,62 & $\%$ \\
\hline & Woman & 68 & 65,38 & $\%$ \\
\hline \multirow{4}{*}{$\begin{array}{l}\text { The Participants' } \\
\text { Position }\end{array}$} & An owner manager & 62 & 59,62 & $\%$ \\
\hline & A professional manager & 11 & 10,58 & $\%$ \\
\hline & Senior Staff & 27 & 25,96 & $\%$ \\
\hline & Other & 4 & 3,85 & $\%$ \\
\hline \multirow{7}{*}{ Education } & Elementary School & 12 & 11,54 & $\%$ \\
\hline & Junior High School & 13 & 12,50 & $\%$ \\
\hline & Senior High School & 41 & 39,42 & $\%$ \\
\hline & Diploma & 9 & 8,65 & $\%$ \\
\hline & Undergraduate & 25 & 24,04 & $\%$ \\
\hline & Master & 4 & 3,85 & $\%$ \\
\hline & Doctor & 0 & 0 & $\%$ \\
\hline \multirow{6}{*}{ Work Experience } & Less than 1 year & 14 & 13,46 & $\%$ \\
\hline & $1-5$ years & 30 & 28,85 & $\%$ \\
\hline & $6-10$ years & 18 & 17,31 & $\%$ \\
\hline & $11-15$ years & 10 & 9,62 & $\%$ \\
\hline & $16-20$ years & 9 & 8,65 & $\%$ \\
\hline & More than 20 years & 23 & 22,12 & $\%$ \\
\hline
\end{tabular}


The participants were dominated by women $(65,38 \%)$ and men accounted for $34,62 \%$. A possible reason why the batik industry is dominated by women is creating batik products need art skill, creativity and patience; therefore women are suitable for the batik industry. The percentage of the participants' position in the firms were an owner manager $(59,62 \%)$, a professional manager $(10,58 \%)$ and senior staff $(25,96 \%)$. In terms of education level, the highest percentage was senior high school $(39,42 \%)$, followed by bachelor degree $(24,04 \%)$ and junior high school (12,50\%). It seems that high level of formal education is not necessary needs to manage the industry. Lastly, the big three of the participants' work experience were one to five years $(28,85 \%)$, more than 20 years $(22,12 \%)$, and six to ten years $(17,3 \%)$.

Regarding the firms' profile, the following information such as the age of the firms, the firms' leader, the family firms' generation, total asset, and number of employee was analyzed. Table 3 shows the profile of the family firms.

Table 3. Profile of the family firms

\begin{tabular}{|c|c|c|c|c|}
\hline \multirow{5}{*}{ Firms Age } & $1-5$ years & 42 & 40,38 & $\%$ \\
\hline & $5-10$ years & 18 & 17,31 & $\%$ \\
\hline & $10-15$ years & 8 & 7,69 & $\%$ \\
\hline & $15-20$ years & 2 & 1,92 & $\%$ \\
\hline & More than 20 years & 34 & 32,69 & $\%$ \\
\hline \multirow{2}{*}{ Leader } & Family Member & 30 & 28,85 & $\%$ \\
\hline & Professional & 74 & 71,15 & $\%$ \\
\hline \multirow{5}{*}{ Generation } & First Generation & 67 & 64,42 & $\%$ \\
\hline & Second Generation & 28 & 26,92 & $\%$ \\
\hline & Third Generation & 9 & 8,65 & $\%$ \\
\hline & Fourth Generation & 0 & 0 & $\%$ \\
\hline & Fifth Generation & 0 & 0 & $\%$ \\
\hline \multirow{6}{*}{ Asset (in IDR) } & 1 million-less than 500 millions & 62 & 59,62 & $\%$ \\
\hline & 500 millions-less than 1 billion & 22 & 21,15 & $\%$ \\
\hline & 1 billion-less than 3 billions & 10 & 9,62 & $\%$ \\
\hline & 3 billions-less than 5 billions & 1 & 0,96 & $\%$ \\
\hline & 5 billions-less than 7 billions & 5 & 4,81 & $\%$ \\
\hline & More than 7 billions & 4 & 3,85 & $\%$ \\
\hline \multirow{8}{*}{$\begin{array}{l}\text { Number } \\
\text { Employee }\end{array}$} & Less than 10 people & 48 & 46,15 & $\%$ \\
\hline & 10-25 people & 29 & 27,88 & $\%$ \\
\hline & 26-40 people & 15 & 14,42 & $\%$ \\
\hline & $41-55$ people & 6 & 5,77 & $\%$ \\
\hline & 56-70 people & 0 & 0 & $\%$ \\
\hline & 71-85 people & 3 & 2,88 & $\%$ \\
\hline & 86-100 people & 2 & 1,92 & $\%$ \\
\hline & More 100 people & 1 & 0,96 & $\%$ \\
\hline
\end{tabular}

The big three of the firms' age were 1-5 years $(40,38 \%)$, more than 20 years $(32,69 \%)$ and $5-10$ years $(17,31 \%)$. It means that around $40 \%$ of the firms were relatively new. The analysis also revealed that family member dominated in the leadership of the firms $(71,15 \%)$ and leaders from professional only accounted for $28,85 \%$. The high percentage of the family member involves in the firms' management is in line with the characteristic of a family firm. Most of the participant firms were managed by the first generation $(64,42 \%)$ and the second generation $(26,92 \%)$. A possible reason behind the fact that the first generation was the biggest proportion who manages the firms is most of the surveyed firms age is 1 to 5 years. More than a half of the firms have total asset under IDR 500 million $(59,62 \%)$ and $21,15 \%$ of the firms in the range between IDR 500 million to less than one billion. Regarding number of employees, more than forty percent of the firms have less than 10 workers $(46,15 \%)$, and nearly $30 \%$ of the firms have 10 to 25 workers. Based on the amount of total asset and the number of employee, it can be concluded that the participant firms were dominated by small and medium family firms.

\subsection{Cronbach Alphas}

A reliability analysis for each multi-item construct was conducted by using Cronbach's coefficient alpha and table 4 displays the result of the analysis. Overall scores of the coefficient alpha were above the cut-off point 0,7 
recommended by Nunally (1978). The marginally lower scores for market turbulence and competitive intensity could be due to the few items in the construct.

Table 4. Reliability analysis for multi-item scales

\begin{tabular}{ll}
\hline Scale & Coefficient Alpha \\
\hline Proactive Market Orientation & 0.77 \\
Responsive Market Orientation & 0.71 \\
Market Turbulence & 0.66 \\
Competitive Intensity & 0.68 \\
Business Performance & 0.81 \\
\hline
\end{tabular}

\subsection{MO-Performance Relationship}

Table 5 contains the correlations matrix of the key variables in the analysis. The correlation was measured by using the Pearson correlation coefficient. Worth mentioning was the significant positive correlation between proactive and responsive MO (.545). Proactive MO, responsive MO, and competitive intensity have significant positive correlations with both the financial and non-financial performance. Market turbulence had significant positive correlation with financial business performance. Positive correlation between the financial and non-financial performance elements was found. The three control variables have no association with financial and non-financial performance.

Table 6 displays the result of the regression analyses measuring the impact of MO on business performance which consists of two dimensions (financial and non-financial performance). All models calculated significant. Proactive MO has a significant $(\mathrm{p}<.05)$ and positive $(.327)$ impact upon financial performance and it also has a significant $(\mathrm{p}<.05)$ and positive $(.560)$ impact upon non-financial performance. Therefore hypothesis 1 was accepted. The result was in line with the result of the vast majority of MO studies (Kirca, Jayachandran \& Bearden (2005).

Table 5. Correlations

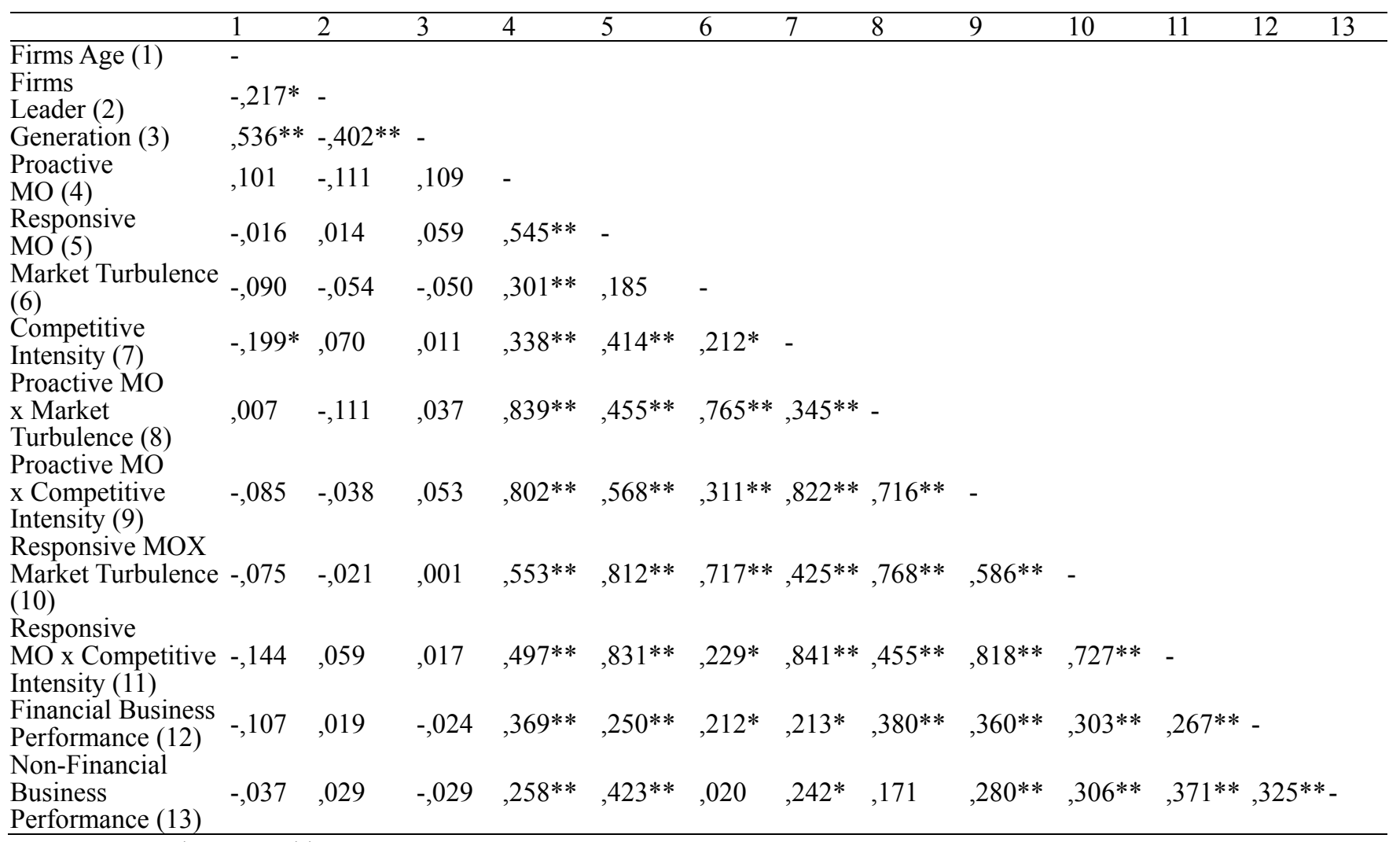

$$
\mathrm{n}=104 ; \mathrm{p}<.05 ; * * \mathrm{p}<.01
$$


Hypothesis 2 predicted that responsive MO has a positive impact on business performance. The regression analysis showed that hypothesis 2 was supported since responsive MO has a significant $(\mathrm{p}<.05)$ and positive $(.317)$ effect on financial performance and it also has a significant $(\mathrm{p}<.05)$ and positive $(.375)$ impact on non-financial performance.

The result was in line with the result of the vast majority of MO studies (Kirca, Jayachandran \& Bearden (2005). Therefore, the finding that MO significantly and positively influences business performance of the family firms in the batik industry in Yogyakarta province corroborates conclusions of the majority of MO studies that investigated the MO-performance link.

Table 6. Test for main effects results of regression analyses

\begin{tabular}{|c|c|c|c|c|}
\hline \multirow[b]{3}{*}{ Proactive MO } & \multicolumn{2}{|c|}{$\begin{array}{l}\text { Financial } \\
\text { Performance }\end{array}$} & \multicolumn{2}{|c|}{$\begin{array}{l}\text { Non-financial } \\
\text { performance }\end{array}$} \\
\hline & $\beta$ & S.E & $\beta$ & S.E \\
\hline &, $327 *$ & 124 &, $560^{*}$ & 129 \\
\hline Responsive MO & $317 *$ & 125 & $375^{*}$ & 130 \\
\hline Firms Age &,- 094 & 045 & 046 &, 047 \\
\hline Firms Leader &, 035 &, 150 &,- 012 & 155 \\
\hline Generation &,- 017 &, 120 &,- 115 & 124 \\
\hline Market Turbulence &, 086 & 126 &,- 095 & 130 \\
\hline Competitive Intensity &, 051 &, 139 & 099 & ,144 \\
\hline $\mathrm{F}$ & 2,76 & & 3,38 & \\
\hline $\mathrm{R}^{2}$ (significance of $\mathrm{F}$ test) & $17^{*}$ & & $20 *$ & \\
\hline Adjusted $\mathrm{R}^{2}$ (significance of $F$ test) &, $11^{*}$ & &, $14^{*}$ & \\
\hline
\end{tabular}

\subsection{Moderators of MO-Performance Relationship}

Hypotheses 3 through 6 postulated that the relationship between MO (proactive and responsive) and business performance were moderated by market turbulence and competitive intensity. Table 7 shows the result of regression analysis with moderator variables. The table indicated that among the predictors in all models; there were four predictors that positively and significantly contribute to the relationship between MO-business performance relationship (model 1, model 4, model 7, and model 10). The table also indicated that there were no significant contributions of moderator variables (market turbulence and competitive intensity) on MO-business performance relationship. Based on the result, it can be concluded that hypotheses 3 through 6 were rejected.

Table 7. Tests for moderator variables effect on MO-Performance relationship

\begin{tabular}{|c|c|c|c|c|}
\hline & & $\mathrm{R}^{2}$ & $\begin{array}{l}\mathrm{R}^{2} \\
\text { change }\end{array}$ & $\begin{array}{l}\text { Sig F } \\
\text { change }\end{array}$ \\
\hline \multicolumn{5}{|c|}{ Proactive MO VS Performance } \\
\hline \multirow{3}{*}{ H3 Market Turbulence } & \multirow{3}{*}{$\begin{array}{l}\text { (Model 1) Predictors: ProMO } \\
\text { (Model 2) Predictors: ProMO; MarkTurb } \\
\text { (Model 3) Predictors: ProMO; } \\
\text { MarkTur; ProMOxMarkTur }\end{array}$} & ,133 & , 133 & 000 \\
\hline & & ,133 &, 000 & ,957 \\
\hline & & ,135 & 001 & ,683 \\
\hline \multirow{3}{*}{ H4 Competitive Intensity } & \multirow{3}{*}{$\begin{array}{l}\text { (Model 4) Predictors: ProMO } \\
\text { (Model 5) Predictors: ProMO; CompIntens } \\
\text { (Model 6) Predictors:ProMO; } \\
\text { CompIntens; ProMOxCompIntens }\end{array}$} & 135 & 135 &, 000 \\
\hline & &, 163 & , 028 & , 072 \\
\hline & & ,176 & 013 & ,209 \\
\hline \multicolumn{5}{|c|}{ Responsive MO VS Performance } \\
\hline \multirow{3}{*}{ H5 Market Turbulence } & \multirow{3}{*}{$\begin{array}{l}\text { (Model 7) Predictors: ResMO } \\
\text { (Model 8) Predictors: ResMO; MarkTurb } \\
\text { (Model 9) Predictors: ResMO; } \\
\text { MarkTur; ResMOxMarkTur }\end{array}$} & , 187 & , 187 & 000 \\
\hline & &, 188 & 001 & 694 \\
\hline & & , 188 & 000 & 878 \\
\hline \multirow{3}{*}{ H6 Competitive Intensity } & \multirow{3}{*}{$\begin{array}{l}\text { (Model 10) Predictors: ResMO } \\
\text { (Model 11) Predictors: ResMO; } \\
\text { CompIntens } \\
\text { (Model 12) Predictors:ResMO; } \\
\text { CompIntens; ResMOx CompIntens }\end{array}$} & ,186 & , 186 & 000 \\
\hline & & ,198 & 013 & ,213 \\
\hline & & ,222 &, 024 & 085 \\
\hline
\end{tabular}


In the present study, the result of MO-business performance relationship in the family firm context was consistent with the vast majority of MO studies; however the role of moderator variables (market turbulence and competitive intensity) provided non-significant contribution to the MO-business performance relationship. In a meta-analysis study conducted by Kirca, Jayachandran \& Bearden (2005), they classified studies that explore the moderators of the market orientation-performance relationship into 'supportive', 'opposite' and 'non-significant effects'. They found that only 5 of 14 studies, market turbulence was found to moderate the MO-performance relationship in turbulent market. In their conclusion, they added that based on the nonparametric sign test result: market turbulence, competitive intensity and technological turbulence did not support the variables to moderate the relationship between MO-performance.

\section{Conclusions and Implications}

Based on the present study result, it may be concluded that the family firms in the batik industry in Yogyakarta province have adopted practices that in line with the concept of MO without proper understanding or knowledge about the concept. Such practices have proven able to enhance the family firms' performance. Despite the batik products in Indonesia are flooded by cheap imported products, the batik design in the market are easily copied and hijacked, however many the family firms survive and continue contribute to the economy development. In addition, the descriptive statistic shows that there are many new firms (less than five years) were established dominate the industry. It seems that in the future, the batik industry in Indonesia is continued to grow and many firms see the opportunity. The growth of the industry is supported by custom of Indonesian people to wear batik clothes in many occasion and income generated from export to some developed countries.

\subsection{Managerial Implications}

The study result provides lessons learned that may implemented by policy makers or top management of the family firms in the batik industry in Indonesia. Top management of the family firms can enhance the business performance by managing and emphasizing MO effectively. Descriptive statistics show that the firms were dominated by small scale of firms and the firms also managed dominantly by family members. Therefore, a challenge that may emerge is how MO in the family firms can be effectively implemented and can be connected into interdepartmental. As suggested by Kirca, Jayachandran \& Bearden (2005:37) that 'centralization may not hamper MO, which implies that an organization with a centralized decision-making structure can prevent that structure from impeding the information flow that critical for MO by focusing on top management emphasis, interdepartmental connectedness and appropriate reward systems'. Furthermore, it is important for top management to enhance their knowledge about MO and strategy to implement it.

Regarding the moderator variables, it is important for top management to find and to measure of the mediating variables other than market turbulence and competitive intensity that may be useful for tracking the impact of $\mathrm{MO}$ on performance. The variables such as innovativeness, customer loyalty and quality may be employing to enhance the MO-performance relationship.

\subsection{Limitations of the Study}

The present study was also subject to some limitation. First, this study employed cross-section analysis; therefore it is not possible to track the change of MO-performance relationship and causal interpretations must be made with care. Second, this study used non-random sampling and the sample may not represent the population; therefore the study result must be interpreted carefully. Third, this study only employed subjective performance measurement; in the future study the comparison between subjective and objective performance measurement is suggested. Finally, the study was conducted in the city of Yogyakarta; therefore the study's results might not represent all the Indonesian batik family firms.

\section{References}

Agarwal, S., Erramilli, K. M., \& Dev, C. D. (2003). Market Orientation and Performance in Service Firms: Role of Innovation. Journal of Services Marketing, 17(1), 68-82. http://dx.doi.org/10.1108/03090560810852922

Bennett, R., \& Cooper, R. (1979). Beyond the Marketing Concept. Business Horizons, 22(3), 76-83. http://dx.doi.org/10.1016/0007-6813(79)90088-0

Budiono, G., \& Vincent, A. (2010). Batik Industry of Indonesia: The Rise, Fall and Prospect. Studies in Business and Economics, 5(3), 156-170.

Cassilas, J. C., Moreno, A. M., \& Barbero, J. L. (2010). A Configurational Approach of the Relationship Between Entrepreneurial Orientation and Growth of Family Firms. Family Business Review, 23(1), 27-44. http://dx.doi.org/10.1177/08944866509345159 
Deshpande, R., Farley, J. U., \& Webster, F. E. (1993). Corporate Culture, Customer Orientation and Innovativeness in Japanese Firms: A Quadrad Analysis. Journal of Marketing, 57, 23-37. http://dx.doi.org/10.2307/1252055

Ellis, P. D. (2006). Market Orientation and Performance: A Meta Analysis and Cross-National Comparisons. Journal of Management Studies, 43, 1089-1107. http://dx.doi.org/10.1111/j.1467-6486.2006.00630.x

Fiorito, S., \& LaForge, R. (1996). A Marketing Strategy Analysis of Small Retailers. American Journal of Small Business, 10(4), 7-17.

Homburg, C., \& Pflesser, C. (2000). A Multi Layer Model of Market-Oriented Organizational Culture: Measurement Issues and Performance Outcomes. Journal of Marketing Research, 37, 449-462. http://dx.doi.org/10.1509/jmkr.37.4.449.18786

Houston, F. S. (1986). The Marketing Concept: What It Is What It Is Not. Journal of Marketing, 50, 81-87. http://dx.doi.org/10.2307/1251602

Hult, T. G., \& Ketchen, D. J. (2001). Does Market Orientation Matter? A Test of the Relationship between Positional Advantage and Performance. Strategic Management Journal, 22(9), 899-906. http://dx.doi.org/10.1002/smj.197

Im, S., \& Workman, J. P. (2004). Market Orientation, Creativity and New Product Performance in $\begin{array}{llll}\text { High-Technology Firms. Journal of } & \text { Marketing, 68(2), }\end{array}$ http://dx.doi.org/10.1509/jmkg.68.2.114.27788

Jaworski, B. J., \& Kohli, A. K. (1996). Market Orientation: Review, Refinement and Roadmap. Journal of Market-Focused Management, 1(2), 119-135. http://dx.doi.org/10.1007/BF00128686

Kirca, A. H., Jayachandran, S., \& Bearden, W. O. (2005). Market Orientation: A Meta-Analytic Review and Assessment of Its Antecedents and Impact on Performance. Journal of Marketing, 69, 24-41. http://dx.doi.org/10.1509/jmkg.69.2.24.60761

Kohli, A. K., \& Jaworski, B. J. (1990). Market Orientation: The Construct, Research Propositions and Managerial Implications. Journal of Marketing, 54, 1-18. http://dx.doi.org/10.2307/1251866

Kohli, A. K., \& Jaworski, B. J. (1993). Market Orientation: Antecedents and Consequences. Journal of Marketing, 57(3), 53-70. http//dx.doi.org/10.4135/9781452231426

Kotler, P., \& Keller, K. (2011). Marketing Management (14th ed.). Englewood Cliffs, NJ: Prentice Hall.

Lusch, R. F., \& Laczniak, G. R. (1987). The Evolving Marketing Concept, Competitive Intensity and Organizational Performance. Journal of the Academy of Marketing Science, 15, 1-11. http://dx.doi.org/10.1007/BF02722166

Narver, J. C., \& Slater, S. F. (1990). The Effect of Market Orientation on Business Profitability. Journal of Marketing, 54, 20-35. http://dx.doi.org/10.2307/1251757

Narver, J. C., Slater, S. F., \& MacLachlan, D. L. (2004). Responsive and Proactive Market Orientation and New-Product Success. Journal of Product Innovation Management, 21, 334-347. http://dx.doi.org/10.1111/j.0737-6782.2004.00086.x

Nunally, J. (1978). Psychometric Theory (2nd ed.). New York: McGraw-Hill.

Pearce, A., Freeman, E., \& Robinson, R. (1987). The Tenuous Link between Formal Strategic Planning on Financial Performance. Academy of Management Review, 13, 658-675. http://dx.doi.org/10.5465/AMR.1987.4306718

Robinson, R., \& Pearce, J. (1988). Planned Patterns of Strategic Behavior and Their Relationship to Business-Unit Performance. Strategic Management Journal, 9, 43-60. http://dx.doi.org/10.1002/smj.4250090105

Sandvik, I. L., \& Sandvik, K. (2003). The Impact of Market Orientation on Product Innovativeness and Business Performance. International Journal of Research in Marketing, 20(4), 355-376. http://dx.doi.org/10.1016/j.jiresmar.2003.02.002

Venkatraman, N., \& Ramanujam, P. (1986). Measurement of Business Performance in Strategic Research: A Comparison Approach, Academy of Management Review, 11, 801-814. http://dx.doi.org/10.2307/258398

Zachary, M. A., McKenny, A., Short, J. C., \& Payne, G. T. (2011). Family Business and Market Orientation: Construct Validation and Comparative Analysis. Family Business Review, 24(3), 233-251. http://dx.doi.org/10.1177/0894486510396871 


\section{Copyrights}

Copyright for this article is retained by the author(s), with first publication rights granted to the journal.

This is an open-access article distributed under the terms and conditions of the Creative Commons Attribution license (http://creativecommons.org/licenses/by/3.0/). 